STUDIA I PRACE WYDZIAŁU NAUK EKONOMICZNYCH I ZARZĄDZANIA NR 39, t. 1

DOI:10.18276/sip.2015.39/1-09

\author{
Joanna Wiśniewska* \\ Uniwersytet Szczeciński
}

\title{
STRATEGIA TECHNOLOGICZNA W ROZWOJU WSPÓŁCZESNYCH ORGANIZACJI
}

\begin{abstract}
Streszczenie
Ukształtowany pod presją zmian otoczenia nowy paradygmat organizacji lokujący w jej centralnym miejscu zasoby wiedzy zmienia nieco sens i zakres strategii technicznej. $\mathrm{Z}$ tego względu głównym celem artykułu jest określenie istoty i zakresu strategii technologicznej w rozwoju współczesnych organizacji.
\end{abstract}

Słowa kluczowe: strategia, technologia, organizacja

\section{Wprowadzenie}

Jednym z powszechnie artykułowanych współcześnie problemów rozwoju organizacji na całym świecie jest potrzeba innowacyjności. Przy czym podkreśla się jej niezwykle istotny i strategiczny wymiar, bowiem w aktualnych realiach gospodarczych o efektach i przyszłych perspektywach rozwojowych decydują w znacznej mierze charakter i intensywność różnorodnych przedsięwzięć innowacyjnych, dostosowujących zachowanie organizacji do wymogów globalnego rynku oraz stanu, struktury, złożoności i dynamiki otoczenia.

\footnotetext{
*Adres e-mail: gjowi@wneiz.pl.
} 
W gospodarce globalnej, z którą mamy współcześnie do czynienia, występują określone trendy o charakterze naukowym i technologicznym, obejmujące: ${ }^{1}$

- wykładniczy wzrost wartości naukowej i technologicznej wiedzy,

- globalizację nauki i technologii,

- akcelerację dyfuzji wiedzy technologicznej i naukowej.

Biorąc pod uwagę to, jak również burzliwą zmienność otoczenia, stwierdzić należy, że współczesne podmioty zmuszone są do stałej redefinicji przyjętych modeli biznesu, wdrażania nowych produktów (usług), procesów czy sposobów zorganizowania prowadzonej działalności. Działania takie są niezbędne, bowiem ich zaniechanie grozi utratą pozycji konkurencyjnej, spadkiem wartości organizacji, co w rezultacie może prowadzić do utraty możliwości efektywnego funkcjonowania.

Wśród szeregu strategicznych zasobów organizacji współcześnie szczególnego znaczenia $\mathrm{z}$ uwagi na rolę $\mathrm{w}$ procesie uzyskiwania wysokiego i trwałego poziomu konkurencyjności nabiera technologia. Jej znaczenie i rola w organizacji uległy istotnej zmianie, co jest efektem ukształtowanego pod presją zmian otoczenia nowego paradygmatu organizacji opartego współcześnie na szeroko rozumianych zasobach wiedzy.

Od organizacji wymaga się dziś, aby stała się „inteligentna”, przez co rozumie się m.in. umiejętność osiągania wysokich wskaźników wzrostu ekonomicznego oraz wysokiej pozycji rynkowej dzięki umiejętnemu wykorzystaniu zasobów wie$\mathrm{dzy}^{2}$. Wśród filarów sukcesu tego typu organizacji wskazać można obok kapitału ludzkiego innowacje, kreatywność i nowe technologie, co w rezultacie oznacza, że kluczowe znaczenie ma postrzeganie ich jako strategicznych zasobów organizacji. Tradycyjne formy konkurowania ustępują bowiem współcześnie miejsca wskazanym atrybutom, w zawiązku z czym istotne jest skupienie szczególnej uwagi na wskazanych zasobach i uwzględnienie ich $\mathrm{w}$ centralnym miejscu projektowanych strategii rozwoju.

${ }^{1}$ Por. W.B. Zehner, D.M. Trzmielak, E. Gwarda-Gruszczyńska, Value Creation Via Technology Commercialization International Education Programs American and Polish Perspectives Based on Experience, EQVALL, Improvement Quality of Life-long Learning, University of Economics in Bratislava, Pezinak 2008, s. 126-135.

2 Temat organizacji inteligentnych jest szeroko omawiany w literaturze, zob. np. S. Łobejko, Trendy rozwojowe inteligentnych organizacji w globalnej gospodarce, ekspertyza przygotowana przez EMAR Research Marketing, Warszawa 2009; Inteligentne organizacje - zarzadzanie wiedza i kompetencjami pracowników, Raport PARP, Warszawa 2010. 


\section{Istota technologii}

Odpowiedź na pytanie, czym jest technologia i jaka jest jej istota, jest niezwykle skomplikowana. Studia literatury przedmiotu ukazują szerokie zastosowanie tego terminu, a także pozwalają przywołać szereg różnych definicji, których analiza skłania do stwierdzenia, iż właściwe zrozumienie istoty technologii oraz oceny jej roli, a także znaczenia w danym systemie wymaga rozpatrywania jej w określonym kontekście.

Tradycyjnie technologia $\mathrm{w}$ organizacji była postrzegana głównie jako tzw. hardware (fizyczne maszyny i urządzenia) lub zespół zarówno środków materialnych, jak i metod stosowanych w działalności gospodarczej ${ }^{3}$. Jednak, jak twierdzi M. Heidegger ${ }^{4}$, istota technologii jest niezwykle złożona i wcale nie ma charakteru technologicznego. Podobnie zauważa K. Weick, wskazując możliwość wielu akceptowalnych interpretacji tej kategorii ${ }^{5}$.

W naukach technicznych technologia definiowana jest zwykle jako całokształt wiedzy dotyczącej metod wytwarzania określonego produktu albo uzyskania określonego efektu. Z kolei nurty odwołujące się do społecznej konstrukcji technologii wskazują następujące elementy definiujące technologię ${ }^{6}$ :

a) fizyczne obiekty (artefakty) - maszyny i urządzenia będące materialnym przejawem technologii;

b) procesy - konieczne, aby przy użyciu specjalistycznej wiedzy przekształcić obiekty na wejściu (materiały, surowce, półfabrykaty) w obiekty wyjściowe (wyroby, usługi);

c) wiedza ludzka - niezbędna dla wykorzystania artefaktów i procesów.

3 Por. W. Orlikowski, The Duality of Technology. Rethinking the Concept of Technology in Organizations, „Organization Science” 1992, No. 3, s. 399; Nauka i technika w rozwoju spoteczno-gospodarczym, red. L. Białoń, T. Obrębski, PWN, Warszawa 1989, s. 11.

4 Zob. M. Heidegger, The Question Concerning Technology and Other Essays, Garland Publishing, New York-London 1977, s. 4.

5 Zob. K. Weick, Technology as Equivoque. Sense-making in New-technology, w: K. Weick, Making Sense of the Organization, Blackwell, Oxford 2000, s. 148.

6 Por. The Social Construction of Technological Systems: New Directions in the Sociology and History of Technology, red. W.E. Bijker, T.P. Hughes, T. Pinch, The MIT Press, Cambridge-London 1989, s. 4. 
W tym ujęciu proces powstawania nowych technologii dotyka kontekstu symbolicznego i kulturowego obejmującego normy kulturowe, stosunki społeczne oraz praktykę projektowania i wytwarzania produktów społecznie użytecznych ${ }^{7}$.

Skrajna koncepcja technologii wiąże ją ze zjawiskami społeczno-technologicznymi, wychodzącymi poza krąg problemów dotyczących urządzeń, umiejętności ludzkich i systemów zarządzania. W granice technologii w tym przypadku włączone są również procesy kulturalne, społeczne i psychologiczne, zaliczane do zasadniczych wartości kultury narodowej.

Trzonem technologii jest bez wątpienia wiedza, zarówno naukowa (abstrakcyjna) i empiryczna, jak również zmaterializowana i niematerialna. Współczesne spojrzenie na technologię jako zasób organizacji wymaga postrzegania jej jako swoistego środowiska, które charakteryzuje się m.in. świadomością istnienia specyficznych zasobów umożliwiających obmyślanie i wdrażanie różnych rozwiązań dla rozwiązania poszczególnych problemów. Obejmuje zatem szereg składowych, takich jak: brainware, humanware, hardware, software, orgware czy infoware i cysnetware ${ }^{8}$. Zatem istota technologii $\mathrm{w}$ organizacji nie sprowadza się jedynie do określonych aspektów fizycznych, ale obejmuje wiedzę, aspekty społeczne czy zarządcze.

\section{Zakres strategii technologicznej organizacji}

Biorąc pod uwagę fakt, że technologia stała się podstawowym czynnikiem tworzenia potencjału konkurencyjnego oraz realizacji celów strategicznych, istotne jest właściwe określenie strategii technologicznej. Ukształtowany pod presją zmian otoczenia nowy paradygmat organizacji zmienia nieco sens i formy strategii technicznej współczesnych podmiotów.

Do niedawna strategia techniczna traktowana była jako ta część ogólnej strategii podmiotu, która odnosiła się do wyboru przyszłych systemów technicznych (np. baz danych, instalacji przemysłowych, linii produkcyjnych), procesów tech-

7 Por. M.J. Hatch, Teoria organizacji, Wydawnictwo Naukowe PWN, Warszawa 2002, s. 157.

8 Szerzej na temat różnych składowych elementów technologii zob. J. Wiśniewska, Technologia jako strategiczny czynnik innowacyjności organizacji, w: Innowacje i procesy transferu technologii w strategicznym zarządzaniu organizacjami, red. J. Wiśniewska, K. Janasz, Difin, Warszawa 2015, s. $128-129$. 
nologicznych czy produktów9 . Zatem postrzegana była głównie jako plan działań odnoszących się do jednego z podsystemów organizacji - podsystemu technologicznego, których realizacja winna pozwolić osiągnąć podstawowe cele.

Współczesne warunki funkcjonowania, m.in. burzliwe zmiany otoczenia, globalizacja, nasilenie konkurencji, usieciowienie gospodarki, niespotykane dotąd tempo postępu technicznego, skłaniają do postrzegania zmiany technologicznej w wymiarze strategicznym. Oznacza to zatem konieczność zmiany koncepcji strategii z podejścia „produkty-rynki” na „technologie-produkty-rynki” ${ }^{10}$. Takiemu podejściu odpowiada strategia technologiczna obejmująca nie tylko wybór procedur i produktów, lecz także kwalifikacje niezbędne do utrzymania przewagi konkurencyjnej. Chodzi więc nie tylko o umiejętność produkowania czy znajomość technologii, lecz także o rozwijanie umiejętności sprzedaży, zaopatrywania, finansowania działalności, rozumienia otoczenia i zachodzących procesów oraz ich następstw ${ }^{11}$. Oznacza to, zgodnie z koncepcją Nonaki i Takeuchiego, traktowanie organizacji jako systemu tworzącego, przetwarzającego i wykorzystującego szeroko rozumianą wiedzę. $Z$ tego względu strategia technologiczna musi uwzględniać ten nowy sposób postrzegania oraz nową koncepcję tworzenia wartości.

Obecnie strategię techniczną określa się na trzech poziomach $-\mathrm{w}$ zakresie ${ }^{12}$ :

a) kształtowania kompetencji organizacji jako zasobu wiedzy technicznej;

b) badań i prac rozwojowych jako źródła wiedzy i nowych rozwiązań technicznych dla produktów i procesów;

c) procesów technologicznych i systemów wytwarzania produktów (świadczenia usług) jako środków bezpośredniej konfrontacji rynkowej z konkurentami.

9 J. Wiśniewska, op.cit., s. 133-134.

10 Por. M. Marchesnay, Zarządzanie strategiczne. Geneza i rozwój, Poltext, Warszawa 1994, s. 67.

${ }^{11}$ Innowacje w modelach działalności przedsiębiorstw, red. W. Janasz, Wydawnictwo Naukowe Uniwersytetu Szczecińskiego, Szczecin 2003, s. 88.

12 Por. W.A. Kasprzak, K.I. Pelc, Innowacje-strategie techniczne i rozwojowe, Oficyna Wydawnicza Politechniki Wrocławskiej, Wrocław 2012, s. 33. 
Aktualny wymiar strategii technologicznej jest znacznie szerszy, niż to wynika z jej podstawowych zadań obejmujących ${ }^{13}$ :

a) zidentyfikowanie i rozwój tych dziedzin lub dyscyplin, które powinny być połączone w celu usprawnienia technologii funkcjonującej w organizacji;

b) identyfikację i eksplorację nowych kompetencji, które są niezbędne, aby potencjał technologiczny nie stał się przestarzały.

Współcześnie strategia technologiczna określa, jakie domeny wiedzy technicznej podmiot będzie aktywnie wspomagać i rozwijać. Zauważyć należy, że odnosi się ona zarówno do kluczowych (rdzennych), jak i unikalnych kompetencji organiza$\mathrm{cji}^{14}$. Ponadto, kształtowanie oraz realizacja strategii technologicznej wymaga m.in. określenia mechanizmu pozyskiwania i rozwijania kompetencji technologicznych. W związku z tym strategia technologiczna staje się częścią szeroko rozumianej strategii innowacyjnej. W obu przypadkach pojawia się bowiem konieczność dokonania szeregu wyborów strategicznych w odniesieniu do technologii. Sprowadzić je można do odpowiedzi na podstawowe pytania ${ }^{15}$ :

- czy podmiot powinien sam tworzyć technologię?

- czy powinien dokonać zakupu technologii?

- w jaki sposób dokonać transformacji technologii w „sposoby operacyjne” (procedury, procesy)?

- czy przedsiębiorstwo może tworzyć i sprzedawać technologię?

Podmioty aktywne, które posiadają odpowiednie kompetencje w zakresie projektowania rozwiązań technologicznych i zarządzania projektem, często samodzielnie angażują się w tworzenie technologii, podejmując prace $\mathrm{B}+\mathrm{R}$. W takim przypadku efekty podjętych działań mogą znaleźć zastosowanie bezpośrednio u twórcy bądź stanowić przedmiot wymiany handlowej. Zasadniczo, żaden podmiot współcześnie nie jest samowystarczalny w zakresie potrzebnych zasobów technologicznych, co oznacza, że każdy w mniejszym bądź większym zakresie angażuje się w procesy transferowania rozwiązań technicznych. $Z$ tego względu strategie technologiczne uwzględniać muszą również ten aspekt.

13 Por. J. Tidd, J. Bessant, Zarządzanie innowacjami. Integracja zmian technologicznych, rynkowych $i$ organizacyjnych, Wolters Kluwer, Warszawa 2011, s. 286.

14 J. Wiśniewska, op.cit., s. 135.

15 W. Janasz, Innowacyjne strategie rozwoju przemystu, Fundacja na rzecz Uniwersytetu Szczecińskiego, Szczecin 1999, s. 114. 
Niezależnie od podejścia (naukowo-badawcze czy zorientowane na rynek) ${ }^{16}$ przyjętego w kwestii podstaw rozwoju technologii i innowacji, istotne jest dostrzeganie problemu komercjalizacji oraz potencjalnych sposobów ochrony wiedzy technologicznej w procesie formułowania strategii organizacji. Jak wynika $\mathrm{z}$ badań McKinsey Company, włączenie procesów komercjalizacji technologii do stosowanych modeli biznesowych sprzyja osiąganiu celów strategicznych firmy ${ }^{17}$.

Procesy transferu i komercjalizacji technologii dotyczą każdej organizacji. W praktyce występują zarówno w podmiotach pozyskujących technologię wyłącznie na zewnątrz, jak i tych, które samodzielnie bądź we współpracy prowadzą prace $\mathrm{B}+\mathrm{R}$, aby ich efekty wykorzystać na własne potrzeby czy też w formie zabezpieczonej udostępnić innym. Last but not least ten typ procesów jest niezmiernie istotny dla przedsiębiorstw, których kluczową kompetencją jest wiedza naukowa i w związku z tym wyniki prowadzonych badań transferują do innych podmiotów.

$\mathrm{W}$ procesie formułowania strategii technologicznej dokonywany jest wybór technologii, które winny stanowić element portfolio technologicznego organizacji. Przy czym nie chodzi jedynie o te technologie, które są niezbędne do produkcji danego wyrobu ('swiadczenia usług), ale takie, które cechuje największa szansa na sukces naukowy lub komercyjny. Zdaniem A.M. Pawlaka wartość technologii zawarta jest $\mathrm{w}$ trzech rodzajach atrybutów ${ }^{18}$ :

a) technicznych (ekspertyzy i prognozy technologiczne, poziom rozwoju i innowacyjność technologii oraz wartość intelektualną);

b) biznesowych (zastosowanie, wartość wyceny, rynek i jego bariery wejścia oraz pozycja strategiczna);

c) finansowych (wymagania inwestycyjne, potencjalne ryzyko i stopa zwrotu oraz oczekiwana zyskowność).

${ }^{16} \mathrm{~W}$ podejściu naukowo-badawczym charakterystycznym m.in. dla podmiotów prowadzących działalność B + R stawiana jest zwykle teza, że rozwój produktu jest funkcją rozwoju technologii i wiedzy, a także ich komercjalizacji. Z kolei nurt rynkowy wyjaśnia procesy rozwoju technologii i integracji wiedzy jako wypływające $\mathrm{z}$ interpretacji rozwoju nowego produktu.

17 Zob. McKinsey Global Survey: Innovation and Commercialization 2010, McKinsey \& Company 2010.

18 Por. A.M. Pawlak, Wartość klastrów technologii, „Pismo PG” 2010, nr 7, s. 54. 
Odpowiedni wybór wymaga uwzględnienia pozycji konkurencyjnej danej technologii, co oznacza wzięcie pod uwagę dodatkowo takich czynników, jak ${ }^{19}$ :

- rola technologii w strategii biznesowej,

- stopień opanowania kluczowych i unikalnych technologii w regionie,

- zdolność do odgrywania roli lidera technologicznego,

- rozeznanie w technologiach konkurencyjnych/alternatywnych.

Formułowanie strategii technologicznej wymaga również określenia odpowiedniego planu strategicznego w odniesieniu do własności intelektualnej, obejmującej decyzje ${ }^{20}$ :

a) czy i jak chronić własność intelektualną?

b) co jest dla przedsiębiorstwa bardziej opłacalne - prowadzenie własnych inwestycji B + R zmierzających do powstania nowatorskiego rozwiązania czy zarządzanie prawami udzielonymi np. na bazie licencji?

Jak wynika z przedstawionych ram, spektrum zagadnień, jakie powinny zostać ujęte w projektowaniu strategii technologicznej, jest szerokie i świadczy o jej interdyscyplinarnym charakterze. Zrozumienie i kształtowanie tego rodzaju planów wymaga łączenia wiedzy z zakresu m.in. strategii, marketingu, finansów, produkcji oraz badań i rozwoju.

\section{Podsumowanie}

Swoisty imperatyw techniczny kształtujący warunki funkcjonowania oraz wymagania wobec współczesnych organizacji zmienia pozycję zasobów technicznych. Oczekiwana innowacyjność oraz ,inteligencja” organizacji powinny znajdować swoje oparcie we właściwie rozumianej i sformułowanej strategii technologicznej. Nie wystarczy już traktowanie jej jako narzędzia realizacji określonych procesów występujących w poszczególnych obszarach funkcjonalnych (wymiar operacyjny) czy jedynie uznanie technologii za czynnik kreowania przewagi konkurencyjnej (wymiar taktyczny). Potrzeba włączenia szeroko rozumianych zasobów technicz-

19 Pozycjonowanie technologii, red. L. Michalczuk, Społeczna Wyższa Szkoła Przedsiębiorczości i Zarządzania, Łódź 2008, s. 6.

20 Por. A.M. Dereń, Zarządzanie własnościa intelektualnq $w$ transferze technologii, Difin, Warszawa 2014, s. 106, 108. 
nych oraz opracowania adekwatnej strategii technologicznej, pozwalającego na ich centralne umiejscowienie $\mathrm{w}$ procesy kreowania wartości.

Współczesne organizacje wymagają ciągłego ewoluowania swojej prospektywnej działalności, potrzebują nowej filozofii biznesu i nowych sposobów tworzenia wartości, co powoduje, że innowacje i technologia stają się głównym trzonem realizowanych strategii działania.

Konieczność strategicznego podejścia do technologii w organizacji oraz nadania jej znacznie szerszego niż dotychczas wymiaru we współczesnych organizacjach wynika z co najmniej kilku przesłanek, bowiem technologia:

a) jest współcześnie wszechobecna i na tyle silnie powiązana z poszczególnymi obszarami funkcjonowania, iż bez jej udziału praktycznie nie jest możliwe istnienie i działanie organizacji;

b) zawiera elementy szeroko pojmowanej wiedzy i kreatywności, stanowiące jednocześnie podstawę innowacyjności w różnych wymiarach (w zakresie produktów, procesów, modeli biznesu itp.) oraz dające asumpt do tworzenia przewagi konkurencyjnej;

c) wykazuje silne związki z innymi czynnikami innowacyjności (powiązania o charakterze sprzężeń zwrotnych) organizacji, a jej oddziaływanie wykazuje skutki synergiczne.

W tej sytuacji istotne jest właściwe rozumienie i określenie strategii technologicznej. Pojawia się konieczność zmiany w podejściu do zasobów technicznych organizacji, polegająca na znacznie szerszym niż dotychczasowy (operacyjny czy taktyczny) kontekście ich postrzegania, nadaniu im charakteru strategicznego i usytuowaniu w centralnym punkcie procesu tworzenia oraz realizacji strategii rozwoju organizacji. Oznacza to oparcie strategii funkcjonowania przedsiębiorstwa na fundamencie tworzonym przez strategię technologiczną, określającą aktualne i przyszłe domeny wiedzy technicznej, a tym samym wskazującą obszary tzw. rdzennych i unikalnych kompetencji.

\section{Literatura}

Dereń A.M., Zarządzanie wtasnościa intelektualna w transferze technologii, Difin, Warszawa 2014.

Hatch M.J., Teoria organizacji, Wydawnictwo Naukowe PWN, Warszawa 2002. 
Heidegger M., The Question Concerning Technology and Other Essays, Garland Publishing, New York-London 1977.

Innowacje $w$ modelach działalności przedsiębiorstw, red. W. Janasz, Wydawnictwo Naukowe Uniwersytetu Szczecińskiego, Szczecin 2003.

Inteligentne organizacje - zarządzanie wiedza i kompetencjami pracowników, Raport PARP, Warszawa 2010.

Janasz W., Innowacyjne strategie rozwoju przemystu, Fundacja na rzecz Uniwersytetu Szczecińskiego, Szczecin 1999.

Kasprzak W.A., Pelc K.I., Innowacje-strategie techniczne i rozwojowe, Oficyna Wydawnicza Politechniki Wrocławskiej, Wrocław 2012.

Łobejko S., Trendy rozwojowe inteligentnych organizacji $w$ globalnej gospodarce, ekspertyza przygotowana przez EMAR Research Marketing, Warszawa 2009.

Marchesnay M., Zarządzanie strategiczne. Geneza i rozwój, Poltext, Warszawa 1994.

McKinsey Global Survey: Innovation and Commercialization 2010, McKinsey \& Company 2010.

Nauka i technika $w$ rozwoju społeczno-gospodarczym, red. L. Białoń, T. Obrębski, PWN, Warszawa 1989.

Orlikowski W., The Duality of Technology. Rethinking the Concept of Technology in Organizations, „Organization Science” 1992, No. 3.

Pawlak A.M., Wartość klastrów technologii, „Pismo PG” 2010, nr 7.

Pozycjonowanie technologii, red. L. Michalczuk, Społeczna Wyższa Szkoła Przedsiębiorczości i Zarządzania, Łódź 2008.

The Social Construction of Technological Systems: New Directions in the Sociology and History of Technology, red. W.E. Bijker, T.P. Hughes, T. Pinch, The MIT Press, Cambridge-London 1989.

Tidd J., Bessant J., Zarzadzanie innowacjami. Integracja zmian technologicznych, rynkowych i organizacyjnych, Wolters Kluwer, Warszawa 2011.

Weick K., Technology as Equivoque. Sense-making in New-technology, w: K. Weick, Making Sense of the Organization, Blackwell, Oxford 2000.

Wiśniewska J., Technologia jako strategiczny czynnik innowacyjności organizacji, w: Innowacje i procesy transferu technologii $w$ strategicznym zarzadzaniu organizacjami, red. J. Wiśniewska, K. Janasz, Difin, Warszawa 2015.

Zehner W.B., Trzmielak D.M., Gwarda-Gruszczyńska E., Value Creation Via Technology Commercialization International Education Programs American and Polish Perspectives Based on Experience, EQVALL, Improvement Quality of Life-long Learning, University of Economics in Bratislava, Pezinak 2008. 


\title{
TECHNOLOGY STRATEGY \\ IN THE DEVELOPMENT OF MODERN ORGANIZATION
}

\begin{abstract}
A new paradigm formed under the pressure of changes in the environment of the organization, locating the knowledge in the central place, modifies meaning and scope of the technological strategy. Therefore, the main aim of this article is to define the nature and the role of technology in the strategy of development of modern organizations.
\end{abstract}

Translated by Joanna Wiśniewska

Keywords: strategy, technology, organization

JEL Codes: O30, O32 